\title{
Challenges and conservation implications of Polylepis woodlands in the Andean region: Defining actions for sustainable management
}

\section{Juan Pinos ${ }^{1}$}

Key words: Andes, anthropogenic impact, climate change, community management, conservation strategies, endemic species.

Ključne besede: Andi, človekov vpliv, podnebne spremembe, družbeno gospodarjenje, naravovarstvene strategije, endemiti.

Received: 10. 10. 2019

Revision received: 11. 2. 2020

Accepted: 12. 2. 2020

\begin{abstract}
Polylepis species represent one of the most important and endemic woodlands of the mid- and high-elevation regions of the Andean Cordillera. I provide a review of the current situation of Polylepis woodlands, discuss the potential effects of various conservation measures and consider the likely impact of climate change on tree phenology and tree regeneration, aiming to foster the conservation and sustainable management of these woodlands through proper environmental planning. I argue that in addition to the delineation and extension of protected areas, it is essential to incorporate actions such as forestation, forest policies, environmental education and local community participation. To be effective, conservation measures should be implemented in an international transdisciplinary research framework and in harmony with site-specific conditions. Finally, given the likely but uncertain influences of climate change on Polylepis woodlands, further research (and communication of that research) is needed to improve forest management strategies and research priorities for the Andean region.
\end{abstract}

\section{Izvleček}

Vrste rodu Polylepis so med najpomembnejšimi endmičnimi gozdnimi vrstami v srednje in visokogorskem pasu andskih Kordiljer. V članku predstavljamo pregled trenutnega stanja gozdov z vrstami Polylepis, razpravljamo o potencialnih učinkih različnih naravovarstvenih ukrepov in predvidevamo možen učinek podnebnih sprememb na fenologijo dreves in njihovo regeneracijo, vse $\mathrm{z}$ namenom spodbuditi ohranjanje in trajnostno upravljanje teh gozdov z ustreznim okoljskim načrtovanjem. Poleg omejitve in razširitve zavarovanih območij je nujno vključiti različne akcije, kot pogozdovanje, gozdarsko politiko, okoljsko izobraževanje in vključevanje lokalnih skupnosti. Neodvisno od naravovarstvenih strategij, pa moramo vzpostaviti ukrepe, ki bodo temeljili na mednarodnih transdiciplinarnnih raziskavah in bodo $\mathrm{v}$ skladu z lokalnimi rastiščnimi razmerami. Zelo verjetno bodo podnebne spremembe nedoločeno vplivale na rast in razvoj vrst rodu Polylepis, zato $s$ tem člankom želimo vzpodbuditi raziskovalce $\mathrm{k}$ prihodnjim raziskavam $\mathrm{v}$ določene smeri. Rezultati in informacije, ki jih bomo dobili v prihodnjih letih na mednarodnem nivoju bodo ključne za izboljšanje gospodarjenja $\mathrm{z}$ temi gozdovi, izbiro raziskovalnih prioritet in strategij v Andih. 


\section{Introduction}

The Andean Cordillera extends from western Venezuela to Argentina and is considered a global biodiversity hotspot (Myers et al. 2000). The geographic and climatic variability of this region create conditions where organisms develop special adaptations to survive and thrive (Rahbek et al. 2019). One such group of organisms are plants belonging to the genus Polylepis. These slow-growing trees and shrubs represent a large fraction of the natural and native vegetation of the Andes (Kessler 2006). In addition to the climate stabilizing services provided by most woodlands, Polylepis woodlands are especially important for providing critical ecological functions in a vulnerable environment, as well as a variety of environmental goods and services, including hydrological regulation, soil protection and biodiversity conservation, among others (Cranford \& Mourato 2011). Furthermore, they offer critical habitat for endangered and threatened species (e.g., Gareca et al. 2010a, Sevillano et al. 2018).

Due to climate change, Andean ecosystems are increasingly exposed to higher temperatures and changes in precipitation patterns in both directions (increase and decrease) (Urrutia \& Vuille 2009), creating uncertain conditions for the future for the mid- and high-altitudinal ecosystems. The high-elevation Andean areas experience some of the greatest impacts of climate change, of which the retreat of glaciers is the most eye-catching (Francou 2013). Understanding the response to the effects of climate change is of paramount importance for conservation efforts and mitigation in anthropogenic and natural ecosystems.

It is well known that the conservation of tropical forests will help to achieve the UN Sustainable Development Goals (SDGs) (see Swamy et al. 2018); however, there has been a disproportionate focus on tropical rainforests, whereas current conservation strategies for drier Polylepis woodlands fall alarmingly short of this goal. As a first step towards conservation, Andean community must be informed about the problems Polylepis woodlands face so that the most appropriate conservation strategies are implemented.

Here, I review the following aspects: (1) the delineation of the species composition and distribution of the genus Polylepis; (2) the current situation with an outline of the most important challenges Polylepis woodlands face; (3) a description of the species regeneration capacity; (4) discussion of conservation strategies, including a short description of the views of how Polylepis woodlands will respond to climate change; (5) co-development of conservation and preservation strategies among diverse stakeholders that address conservation goals and local livelihoods; and (6) the need for transdisciplinarity in research and educational efforts. The present work is an important complementary study to the review provided by Renison et al. (2018).

\section{Methods}

The Systematic Literature Review (SLR) method proposed by Kitchenham et al. (2007) was used for the review process. Subject-relevant literature was obtained via the Google Scholar search engine. All possible pair combinations of "Polylepis" with the following terms "Andes", "conservation", "climate change", and "local community", using AND as the Boolean search term, were searched. Peer-reviewed journal articles published in three databases, ISI Web of Science, Scopus and Latindex, were selected. In addition, some official reports and theses indexed in Google Scholar with important and relevant information were also considered. This review mainly drew from studies conducted in the Andes region in English and Spanish. Given the vast number of publications, the search was conducted until reach a database with 200 documents, and this study filtered the articles that met the criteria and were in line with the aim and scope of this review. A total of 70 documents (research and review articles, reports, book chapters, and theses) were selected.

\section{Results and discussion}

\section{Polylepis woodlands}

The genus Polylepis (family Rosaceae, tribe Sanguisorbeae) is distributed throughout the Andean region, exclusively (Simpson 1979). The species of this genus are characterized by anemophilous pollination, evergreen foliage, dry fruits, and twisted trunks covered with a red, multi-layered bark (Simpson 1979, Kessler 2006; Figure 1). Polylepis tree species are the highest elevation woody angiosperm, naturally occurring in fragmented forests in areas typically dominated by shrubs or grasses (Goldstein et al. 1994), with a tree line that even grows in elevations over $5000 \mathrm{~m}$ (Rada et al. 2001). The classification of taxa in the genus is a challenge due to the morphological variability within the populations and the extensive hybridization among the different Polylepis species (Romoleroux 1996, Schmidt-Lebuhn et al. 2006). Kessler \& Schmidt-Lebuhn (2006) suggest that hybridization likely takes place among all species of the genus, when they grow in close geographic proximity to each other. Therefore, there is no scientific consensus about the real number of species due to the different classifica- 
tions used, e.g., Bitter (1911) recognized 33 species, Simpson (1979) only 15 species, Kessler \& Schmidt-Lebuhn (2006) 26 species, and more recently Segovia-Salcedo et al. (2018) described 28 species that comprise the Polylepis genus. Given Polylepis species' diversity, Polylepis woodlands are established across broad spatial extents and at mid- and high-elevations, furthermore, Polylepis adaptations have led to certain species exclusively occurring in different habitats, largely differentiated by temperature and precipitation regimes (Kessler 2002).

\section{Current situation and issues facing Polylepis woodlands}

As indicated in several studies, Polylepis woodlands could originally have covered large tracts of the Andean territory (Kessler \& Driesch 1993, Zutta et al. 2012). Currently, Polylepis woodlands form isolated stands, rather than a continuous vegetation cover, and the degree of conservation ranges from deficient to very low. Polylepis woodlands are restricted to specific sites (e.g., rocky slopes and stream edges), which can be attributed in part to the sporadic occurrence of suitable microhabitats and partly to human influence (Simpson 1986). Residual and frag- mented homogenous stands are usually located on exposed foggy mountainsides in self-enriched soils, high in organic matter (Pretell et al. 1985). Slopes are favourable locations because those landscapes provide a habitat with less interspecific competition, less access by cattle and loggers, and better protection against the wind (Smith 1978, Osha 2000). For example, in line with the above, Coblentz \& Keating (2008) and Toivonen et al. (2018) demonstrated that Polylepis fragments have topographic preference that changes with elevation.

There are active debates regarding explanations for the current fragmented network of Polylepis woodlands. Kessler (2002) describes two hypotheses for this distribution: "the hypothesis of a natural fragmentation" and the "hypothesis of a fragmentation by human intervention". Fjeldså (2002) indicated that the strong and continuous anthropogenic pressure over the centuries is the cause for the current patched distribution of the Polylepis woodlands. Recently, Valencia et al. (2018) suggested that precipitation and landscape heterogeneity are the controlling factors for the distribution of Polylepis woodlands in the pre-human period; with the arrival of human activities, a "hyper-fragmentation" took place during the last 1000 years. On the other hand, Gosling et al. (2009)

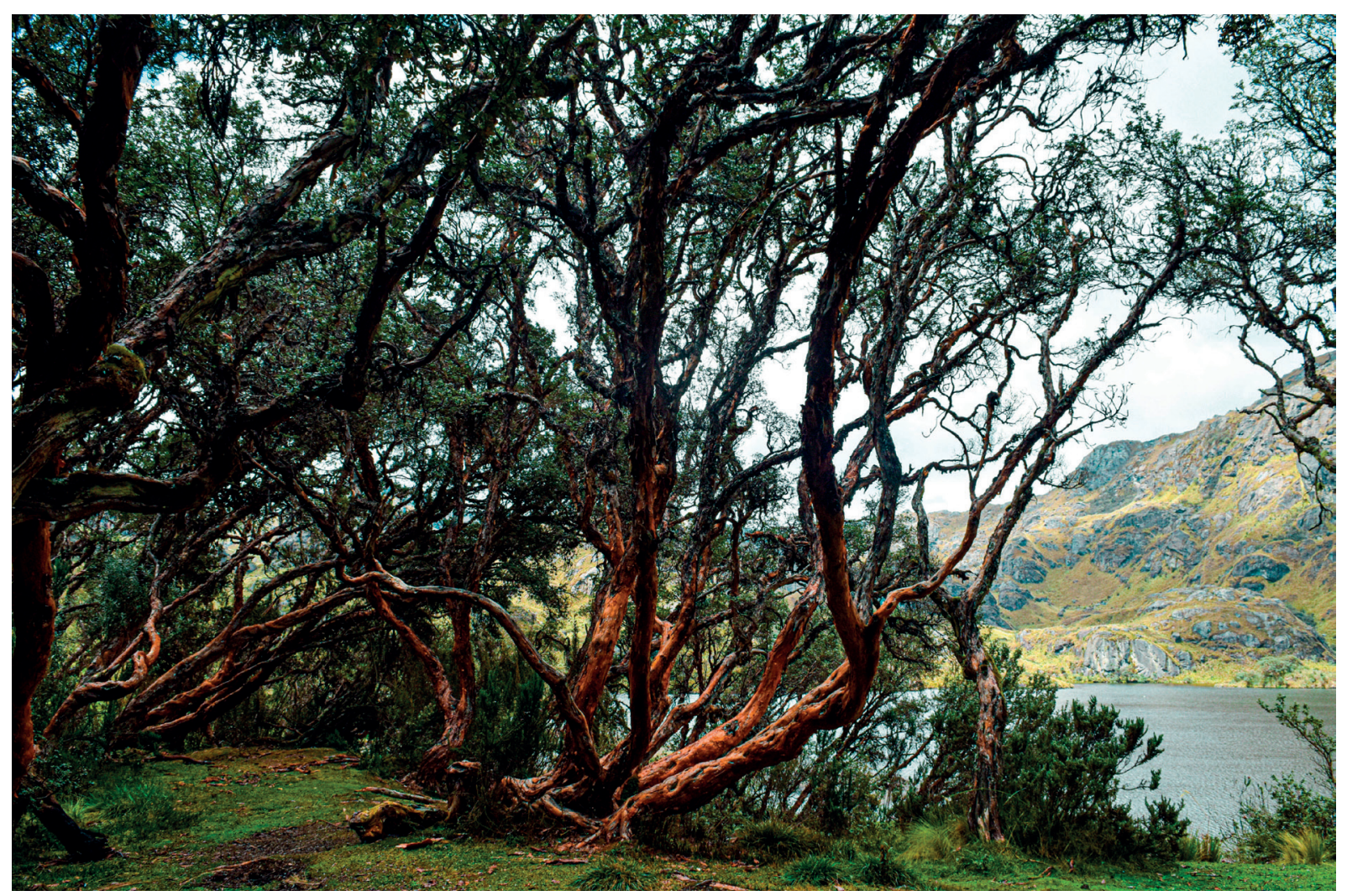

Figure 1: Polylepis reticulata woodland in the Cajas National Park, Azuay, Ecuador (Author: Adrian Sucozhañay).

Slika 1: Gozdovi vrste Polylepis reticulata v narodnem parku Cajas National Park, Azuay, Ekvador (avtor: Adrian Sucozhañay). 
stated that Polylepis did not form permanent continuous woodland before the arrival of humans. It remains unresolved which of these hypothesized causes for the loss of Polylepis woodlands is valid.

Currently, the over-use of resources is considered the prime cause for the loss of Polylepis woodlands. The forests face pressure from livestock grazing, logging, controlled burning, and road expansion (Purcell \& Brelsford 2004), all of which limit the habitat extension and composition (Jameson \& Ramsay 2007). Kessler \& Driesch (1993) concluded that anthropogenic burning presents the greatest threat to the high Andean forests. Renison et al. (2002) and Cierjacks et al. (2008a) confirmed that fire considerably affects the regeneration processes of Polylepis forests by reducing survival, seed production and height growth, while cattle trampling and grazing even at moderate levels seem to have minor consequences for these forest communities (Cierjacks et al. 2008b). However, the influence of grazing should not be underestimated. Renison et al. (2010) demonstrated that livestock has a significant influence on forest soil degradation, and Teich et al. (2005) and Zimmermann et al. (2009) reported that in situations of overgrazing, few young Polylepis plants manage to survive. A combination of both burning and excessive grazing prevent the regeneration of young trees by increasing soil degradation, which affects seed viability (Renison et al. 2004). It can be concluded that human activities influence the density and height of the forest, tree regeneration, and even the genetic constitution of Polylepis populations (Gareca et al. 2013).

Because of continued fragmentation, whether natural or anthropogenic, Polylepis woodlands are now one of the most highly threatened ecosystems in the world (Kessler 2006). Many of the Polylepis species are classified as vulnerable or in danger of extinction within the Red List of Threatened Species (IUCN 2019), and their disappearance is likely altering ecosystem functioning. In fact, the current area coverage of these woodlands is uncertain due to its continuous reduction; moreover, the lack of highquality imagery of the Andean region hinders a proper mapping of the extension of these forests and restrict this analysis to reduced areas (e.g., micro-scale).

\section{Regeneration capacity}

The few studies examining regeneration rates have shown that regeneration took place at the edges of the Polylepis woodlands (Cierjacks et al. 2007, Morales et al. 2018a). Cierjacks et al. (2007) concluded that the edges of the Polylepis stands are areas of high natural recruitment. In the interior of these forests, large numbers of seeds occur, while the seedlings preferentially develop at the edges, indicating that favourable light conditions are required for growth and establishment (Cierjacks et al. 2007). Torres et al. (2008) and Morales et al. (2018a) found that seedling densities decreased with increasing distance away from the forest and suggest that this shortdistance seed dispersal may slow forest expansion. These studies are in agreement with Cáceres (2007) findings which showed using imagery that Polylepis woodlands expand over their same areas, i.e. in areas where woodlands already existed and not over upper floors or free areas adjacent to these woodlands.

The establishment of seedlings at forest edges makes them vulnerable, being an easy target for herbivory because the tender leaves are rich in nutrients and due to the lack of effective physical or chemical defences (Giorgis et al. 2010). The success of the survival of the seedlings is also related to their growth rate, which can change with elevation; unfortunately, vegetative growth is infamously slow in high mountain environments. Hertel \& Wesche (2008) stated that regeneration pattern of Polylepis trees changed markedly along an elevational gradient. For example, Marcora et al. (2008) found for Polylepis australis a decreasing tree vitality, radial growth, seed productivity, and seed mass with increasing elevation, from 900 to $2700 \mathrm{~m}$.

Polylepis species have slow growth rates. For example, Renison et al. (2005) found that seedlings of Polylepis australis in Argentina at elevations of approximately $2000 \mathrm{~m}$ grow in height at a rate of $69 \mathrm{~mm}$ per year, Saravia and Vintimilla (2016) showed that Polylepis reticulata trees at - $3800 \mathrm{~m}$ in Ecuador grow in diameter at a rate of 0.78 and $1.17 \mathrm{~mm}$ per year for young and mature trees, respectively, and Domic \& Capriles (2009) found that Polylepis tarapacana trees at elevations between 4200 and $4600 \mathrm{~m}$ in Bolivia grow in diameter at a rate of $4.6 \mathrm{~mm}$ per year. The study of the growth rates of different Polylepis species has been widely addressed by the scientific community (e.g., Colmenares 2002, Hoch \& Körner 2005, Gareca et al. 2010b, Duchicela 2011, Alvites et al. 2019).

Polylepis species located in high mountain areas are subject to drastic intra-daily temperature variations, suffering low temperatures or even frost (Goldstein et al. 1994, Rada et al. 2009). Low temperatures lead principally to slow metabolism rates due to the inhibition of meristematic activity, hindering growth (Hoch \& Körner 2005). Despite Polylepis species are anatomically and physiologically adapted to tolerate and minimize frost damage (Rada et al. 2001, Azócar et al. 2007), yet, temperature is a decisive factor in limiting tree growth at high elevations (Kessler et al. 2014). Furthermore, biogeochemical cycles are controlled by temperature and are responsible for the low rates of leaf renewal and litter decomposition (Duchicela 2011, Pinos et al. 2017). Rada 
et al. (1996) and Carabajo (2017) demonstrated that the photosynthetic potential of Polylepis species is very high, although it only manifests itself in short periods of time when climatic conditions are favourable, corroborating that temperature is likely the principal abiotic factor controlling tree phenology. The studies presented thus far provide evidence that slow growth rates and the special tree phenology of Polylepis woodlands are linked to temperature, and this condition turns into a negative factor by reducing effective regeneration rates.

\section{Challenges to conservation: pitfalls of strategies and climate change}

Conservation actions aimed at protecting forested areas are key in the conservation of biodiversity through preserving main ecosystem processes, which are crucial for sustainable development (Hoffmann et al. 2011). Current woodland conservation measures in the Andes consisting of the creation of protected areas or restricted forest access are unable to slow down the disappearance of the remaining Polylepis forests (Purcell \& Brelsford 2004, Purcell et al. 2004). The creation of protected areas is an initiative that, in theory, should preserve and conserve the different biological resources contained in them; however, it has several negative aspects, such as the disconnection of ecological areas by blocking corridors (Saura et al. 2018). In fact, there is a wide debate about the efficacy of this tool: we have those who say that this measure has served to conserve and save biodiversity (e.g., Bruner et al. 2001, Geldmann et al. 2013); conversely, there are those who criticize its effectiveness (e.g., Ervin 2003, Parrish et al. 2003). Zutta et al. (2012) found that the lack of protection standards of highland ecosystems throughout the Andean region leave Polylepis woodlands vulnerable since protected areas in the Andean countries represent a low percentage in relation to the extent of Polylepis forests (e.g., Quispe-Melgar et al. 2019). Another key factor of the limited effect of area isolation is the poor management of protected areas; insufficient funds for monitoring and management leads to a decline in conservation capacity. Moreover, the hiring of people who are prepared to live in and care for those areas is not easy. In response to the lack of funds, an alternative option is the creation of community-led private conservation areas. However, to be successful, this action needs to be implemented in accordance with the vision and objectives of the national administration to avoid future conflicts (Bury 2006). Thus, this action, without adequate management and planning, represents an insufficient and inefficient long-term conservation measure. Furthermore, the protection of ecological areas does not stop the expansion of human settlements around those areas, which will inevitably approach them (Wittemyer et al. 2008). Toivonen et al. (2011) found that the distance to villages and roads is correlated to the degradation degree of Polylepis woodlands.

Another of the most common strategies in the Andean countries is forestation (defined in this study as reforestation or afforestation actions), implemented through different programmes and projects, of which the short-term effects are difficult to detect (Simoes-Macayo \& Renison 2015). Long-term monitoring is required to determine the strategy's efficacy up to several decades for planted Polylepis trees due to their slow growth rate. To enhance the conservation level, forestation should aim at not only the promotion of forest expansion but also the conversion of the degraded Polylepis woodlands to healthy woodlands by a mix between regenerating, young, and mature stands, as suggested by Renison et al. (2011). In Polylepis forestation projects seeds must be selected based on mass as an appropriate way to enhance germination (Seltmann et al. 2007).

Forestation must be implemented with caution since: 1) forestation reduce the total water supply to downstream users in most Andean regions (Bonnesoeur et al. 2019), and some Polylepis species could absorb considerable amounts of water (e.g., Polylepis reticulata - Pacheco 2015), which could possibly affect the hydrological cycle of the basin where the forestation process is implemented, 2) forestation with non-native Polylepis species generates hybridization between species and causes local loss of genetic diversity (Schmidt-Lebuhn et al. 2006), and 3) forestation with exotic species, such as eucalyptus and pines, could enhance the loss of native tree species and causes visual damage of the landscape. However, Gareca et al. (2007) found that there are no negative effects on Polylepis subtusalbida regeneration patterns when growing with pine and eucalyptus trees, therefore, the extent to which exotic species affects native species remains unclear.

To further complicate conservation efforts, the effects of climate change superimpose the complex biodiversity distribution patterns along the altitudinal, latitudinal and moisture gradients in the Andes mountain region. Climate change projections for the Andes indicate an increment in temperature in the twenty-first century (Urrutia \& Vuille 2009, Marengo et al. 2010). In contrast, the low temperature of the Andean mountain range was considered one of the main reasons for the slow growth rate and consequently its low rate of effective regeneration. Thus, the question can be asked: how will the increase in temperature influence the growth and regen- 
eration of these woodlands? So far, the phenological responses of Polylepis species to climatic changes have been poorly studied. Marcora et al. (2008) claimed that an increase in temperature could restrict Polylepis australis to its upper distributional altitudes in central Argentina; Gareca et al. (2012), using hydrothermal models, studied the potential effects of global warming in seed germination of Polylepis besseri in the Bolivian Andes and found that with an initial temperature increase, seed germination will increase; however, when maximum temperature modelled surpasses the optimum temperature for seed germination, germination will eventually decrease; and Cuyckens et al. (2016) projected the future potential distribution of Polylepis tarapacana woodlands in the Andean Altiplano under climate change scenarios by using species distribution models, and found that will be severely reduced in the future. These seemingly conflicting findings demonstrate that there are clear gaps in our understanding of how climate change will impact mid- and high-mountain Andean woodlands.

\section{Co-developing conservation and preservation strategies among diverse stakeholders}

Conservation efforts have both benefits and costs: benefits include preserving and strengthening ecosystem functions, whereas costs can include direct management costs as well as lost economic opportunities, such as human development, agriculture, and mining. A common land-management challenge is avoiding placing costs, but not benefits, on marginalized communities (Escobar 1998). Developing these strategies in Andean communities requires direct collaboration with stakeholders in a way that reflects the historical context, addresses land use priorities, promotes climate and environmental justice, and encourages social and collective learning for all participants (e.g. Villarroel et al. 2014).

Renison et al. (2018) and Morales et al. (2018b) pointed out that research communication and cooperation between academic researchers and restoration practitioners are key for the conservation of Polylepis forests. Involving local communities will empower them, open a dialogue, and encourage collegial relationship with the scientific community. In this way, local traditional knowledge and scientific knowledge are interchanged and will likely contribute to the generation of more effective ways to prevent and/or combat negative side-effects of climate change and anthropogenic activities. Experience in the Andes has shown that natural resources management is encouraging the collaboration between villagers and entities (munici- pal, governmental and NGO) with scientists and academic specialists (Dewulf et al. 2004, Mathez-Stiefel et al. 2017).

Two priorities should be education regarding ecosystem services and involvement (and employment) in conservation, towards raising local interest in Polylepis protection (Purcell et al. 2004). Because the valleys of the mid- and high-elevation Andes are intensively farmed and grazed by local communities (e.g. Etter \& Villa 2000), substantial gains could be made by teaching and incentivizing agroforestry techniques, including intercropping, to minimize clearing and other processes that ultimately degrade soils and are less agriculturally sustainable. Many Andean communities are willing to adopt those novel land-use techniques, but at least some traditional components should be contained in the proposed changes to ease their acceptability (e.g. Bernet et al. 2002, Winters et al. 2004). Moreover, solving the problem of unsustainable wood consumption is another key to the successful conservation of Polylepis woodlands, hence cooperation with local villagers will help to identify and develop alternatives for fuelwood and timber (Aucca \& Ramsay 2005). Through collaborative approaches in knowledge generation and knowledge application, new and place specific practices may be developed to protect sociocultural and ecological functions of the landscape.

A conservation action that usually involves several stakeholders is the forestation projects with native tree species. One of the best examples was the planting of approximately one million Polylepis seedlings in Peru from 2001 to 2016. The area comprises a national park and surrounding areas and private conservation areas. The project was led by the Asociación Ecosistemas Andinos (ECOAN), with the collaboration and support of several public and private institutions, NGOs, actors, and local communities (ECOAN 2017). The main focus of ECOAN's conservation philosophy lies on agreements with local people (Aucca \& Ramsay 2005).

From an economic point of view, the generation of additional sources of income for the local people might facilitate their participation in conservation practices (Mitchell \& Eagles 2001). Such profit can be generated, for example, by the development of local ecotourism. Its unique growth form and designation to be the highest elevation forest-type in the world warrants ecotourism potential. However, the impact of tourism and recreation in the Andean ecosystems has been poorly studied (Barros et al. 2015). Therefore, this should not be implemented without a proper environmental planning.

Each conservation action must be in accordance with the vision and mission of the governmental environmental entities at the regional or local scale. Therefore, conservation actions must be previously informed and 
authorized by the stakeholders of the area in question for three primordial reasons: 1) they should not intervene in current governmental or private conservation plans (the most adequate is to join current plans or future phases), 2) they should not repeat actions (this often results in a waste of time and resources), and 3) they should assure legal permits are in place. Andean governments and private organizations must evaluate and reform their strategies to favour long-term development over short-term profit and choose viable and real solutions instead of momentary actions that pursue political or administrative goals. It is important to realize that conservation of Andean ecosystems is only feasible when they are integrally pursued, concurrently tackling the full spectrum of problems the local communities face. Herein, the main needs are health, nutrition and education. Based on the results of Aguilar et al. (2009), I argue that once these needs are covered by any stakeholder, the increases in human health and the well-being of the local inhabitants will likely enhance their motivation to participate in conservation programmes of forest ecosystems.

\section{Transdisciplinary research and education}

The production of new scientific knowledge in the search for solutions to the complex conservation challenges faced by Polylepis woodlands, such as climate change and anthropogenic pressure, requires intensive interaction and agreement among researchers, policymakers, and practitioners. Several gaps exist in our current knowledge about Polylepis; therefore, I suggest that future research efforts across an international transdisciplinary framework should focus on the following aspects: 1) determine the phenological responses of Polylepis species to climatic changes (e.g., tree growth rates, seeding and germination, net primary production, carbon fluxes); 2) establish an actualized baseline of the spatial coverage and transformation processes of Polylepis woodlands; 3) evaluate the effectiveness of protected areas in relation to the degree of conservation; 4) develop accurate projections of Polylepis stands in relation to climate change scenarios; 5) analyse the costs and benefits of conservation, forestation or restoration efforts for Polylepis woodlands; and 6) develop ecohydrology studies (e.g., sap flow measurements, rainfall interception processes, the capture of fog and mist, soil infiltration) for a better understanding the water flux dynamics in Andean forested catchments.

Suitable forest research and development would benefit from an international forest governance cooperation, which will establish the policy, legal and institutional work fronts for international decision-making for these forests. Additionally, environmental education is a must to achieve sustainability, adaptation to climate change, and for stopping, solving and preventing forest destruction. Environmental education will facilitate the development of skills and thoughts oriented towards the conservation of ecosystems in general, and the Polylepis woodlands in particular (Purcell et al. 2004). There is no established universal methodology for environmental education, but its principles are based on educators' knowledge, transdisciplinarity, decision-making, and socio-cultural and economic features.

\section{Conclusions}

Natural forest conservation is a challenge in the midand high-altitudinal Andes, given their vulnerability and exposure to anthropogenic pressure, environmental conditions and climate change. It is recommended that each region tackle the problem of Polylepis woodland loss according to its environmental reality and local possibilities. A few main strategies to promote the conservation of Polylepis woodlands include the delineation of restricted zones (i.e., human interaction is strictly prohibited, only allowed for research purposes), the generation of economic incentives for the conservation of forests, the stimulation of ethical and aesthetic valuation of these environments, and avoidance of future human settlements near protected forests. Parallel aggressive policies must be implemented to regulate, prohibit and control anthropogenic activities on these fragile ecosystems, such as grazing, burning, expansion of the agricultural frontier, and illegal logging. Local administrations ought to play an important role through strategic planning of land use.

Although creating protected areas is the most commonly applied tool, it is not effective without promoting forestation actions for the restoration and recovery of these vulnerable woodlands. Notwithstanding, the consolidation and strengthening of existing protected areas together with the participation of local communities are currently the most effective conservation strategies.

When carrying out forestation projects: 1 ) the use of native species should always be given preference, 2) the use of non-endemic Polylepis species in the area should be avoided due to the high degree of hybridization and the consequent genetic loss, and 3) the hydrological alteration in the basin must be evaluated before the forestation take place.

Transdisciplinary research is a key element for the conservation of Polylepis woodlands, and we need to ensure that scientific knowledge is deployed persuasively into decision-making venues. Interchange of knowledge in combination with continuous environmental education 
programmes are crucial factors in strengthening community adaptation against climate change effects. Moreover, I believe that it is necessary to consolidate international networks for research and conservation purposes.

Finally, the purpose of this review paper was to critically evaluate past work on Polylepis woodlands and to map new research directions that will advance our current understanding of conservation and climate change issues. Additionally, I encourage practitioners to embrace strategies suited to address the SDGs.

\section{Acknowledgements}

I would like to thank Scott Allen for helpful comments on the manuscript. I also thank Ashley Studholme and Carlos Gracia for their valuable observations and suggestions in the early stage of this work.

Juan Pinos (D), https://orcid.org/0000-0002-8021-9197

\section{References}

Aguilar, L. C., Piepenstock, A. \& Burgoa, W. 2009: Especies nativas kewiña (Polylepis sp.) y kiswara (Buddleja sp.) en barreras vivas: una alternativa para reducir la degradación de suelos y mejorar las condiciones de vida en la zona altoandina de Bolivia. Acta Nova 4 (2-3): 425-438.

Alvites, C., Battipaglia, G., Santopuoli, G., Hampel, H., Vázquez, R. F., Matteucci, G. \& Tognetti, R. 2019: Dendrochronological analysis and growth patterns of Polylepis reticulata (Rosaceae) in the Ecuadorian Andes. IAWA Journal 40 (2): 331-S5.

Asociación Ecosistemas Andinos (ECOAN). 2017: Todo por la conservación. Memoria 2017. Available from: https://www.ecoanperu. org/index.html [accessed 09 October 2018]

Aucca, C. \& Ramsay, P. M. 2005: Management of biodiversity and land use in southern Peru: ECOAN's activities to help conserve Polylepis woodlands. Mountain Research and Development 25 (3): 287-289.

Azócar, A., Rada, F. \& García-Núñez, C. 2007: Functional characteristics of the arborescent genus Polylepis along a latitudinal gradient in the high Andes. Interciencia 32 (10): 663-668.

Barros, A., Monz, C. \& Pickering, C. 2015: Is tourism damaging ecosystems in the Andes? Current knowledge and an agenda for future research. Ambio 44 (2): 82-98.

Bernet, T., Hervé, D., Lehmann, B. \& Walker, T. 2002: Improving land use by slope farmers in the Andes: an economic assessment of small-scale sprinkler irrigation for milk production. Mountain Research and Development 22 (4): 375-382.

Bitter, G. 1911: Revision der Gattung Polylepis. Botanische Jahrbücher für Systematik. Pflanzengeschichte und Pflanzengeographie, 45: 564-656.
Bonnesoeur, V., Locatelli, B., Guariguata, M. R., Ochoa-Tocachi, B. F., Vanacker, V., Mao, Z., Stokes, A. \& Mathez-Stiefel, S. L. 2019: Impacts of forests and forestation on hydrological services in the Andes: A systematic review. Forest Ecology and Management 433: 569-584.

Bruner, A. G., Gullison, R. E., Rice, R. E. \& Da Fonseca, G. A. 2001: Effectiveness of parks in protecting tropical biodiversity. Science 291: $125-128$.

Bury, J. 2006: New community-led conservation efforts in the Cordillera Huayhuash, Peru. Mountain Research and Development 26 (2): 180-182.

Cáceres, R. 2007: Movimiento límite de los bosques de Polylepis en relación al retroceso glaciar en la microcuenca Quillcay - Ancash. Acta Universitatis Carolinae, Geographica 42 (1-2): 183-206.

Carabajo, A. 2017: Soportando extremos: Fotosíntesis de Polylepis reticulata en la línea de bosque alto andino en Ecuador. Tesis Máster en Ecología, Gestión y Restauración del Medio Natural. Barcelona, Espańa. Facultad de Biología, Universidad de Barcelona. 36 p.

Cierjacks, A., Rühr, N. K., Wesche, K. \& Hensen, I. 2008b: Effects of altitude and livestock on the regeneration of two tree line forming Polylepis species in Ecuador. Plant Ecology 194 (2): 207-221.

Cierjacks, A., Salgado, S., Wesche, K. \& Hensen, I. 2008a: Post-Fire Population Dynamics of Two Tree Species in High-Altitude Polylepis Forests of Central Ecuador. Biotropica 40 (2): 176-182.

Cierjacks, A., Wesche, K. \& Hensen, I. 2007: Potential lateral expansion of Polylepis forest fragments in central Ecuador. Forest Ecology and Management 242 (2-3): 477-486.

Coblentz, D. \& Keating, P. L. 2008: Topographic controls on the distribution of tree islands in the high Andes of south-western Ecuador. Journal of Biogeography 35 (11): 2026-2038.

Colmenares, M. 2002: Estudio del crecimiento de Polylepis serícea Wedd. en el páramo venezolano. Tesis Licenciada en Biología. Mérida, Venezuela. Facultad de Ciencias, Universidad de los Andes. 57 p.

Cranford, M. \& Mourato, S. 2011: Community conservation and a two-stage approach to payments for ecosystem services. Ecological Economics 71: 89-98.

Cuyckens, G. A. E., Christie, D. A., Domic, A. I., Malizia, L. R. $\&$ Renison, D. 2016: Climate change and the distribution and conservation of the world's highest elevation woodlands in the South American Altiplano. Global and Planetary Change 137: 79-87.

Dewulf, A., Craps, M. \& Dercon, G. 2004: How issues get framed and reframed when different communities meet: a multilevel analysis of a collaborative soil conservation initiative in the Ecuadorian Andes. Journal of Community \& Applied Social Psychology 14 (3): 177-192.

Domic, A. I. \& Capriles, J. M. 2009: Allometry and effects of extreme elevation on growth velocity of the Andean tree Polylepis tarapacana Philippi (Rosaceae). Plant Ecology 205 (2): 223-234.

Duchicela, S. A. 2011: Estudio sobre crecimiento radial, intercambio y descomposición foliar de tres especies de Polylepis (Rosaceae) en dos localidades de los Andes ecuatorianos. Tesis Licenciada en Ciencias Biológicas. Quito, Ecuador. Facultad de Ciencias Exactas y Naturales, Pontificia Universidad Católica del Ecuador. 103 p.

Ervin, J. 2003: Protected area assessments in perspective. BioScience 53 (9): 819-822. 
Escobar, A. 1998: Whose knowledge, whose nature? Biodiversity, conservation, and the political ecology of social movements. Journal of Political Ecology 5 (1): 53-82.

Etter, A. \& Villa, L. A. 2000: Andean forests and farming systems in part of the Eastern Cordillera (Colombia). Mountain Research and Development 20 (3): 236-245.

Fjeldså, J. 2002: Polylepis forests-vestiges of a vanishing ecosystem in the Andes. Ecotropica 8 (2): 111-123.

Francou, B. 2013: El rápido retroceso de los glaciares en los Andes tropicales: Un desafío para el estudio de la dinámica de los ecosistemas de alta montaña. Ecología en Bolivia 48 (2): 69-71.

Gareca, E. E., Fernández, M. \& Stanton, S. 2010b: Dendrochronological investigation of the high Andean tree species Polylepis besseri and implications for management and conservation. Biodiversity and Conservation 19 (7): 1839-1851.

Gareca, E. E., Hermy, M., Fjeldså, J. \& Honnay, O. 2010a: Polylepis woodland remnants as biodiversity islands in the Bolivian high Andes. Biodiversity and Conservation 19 (12): 3327-3346.

Gareca, E. E., Martinez, Y. Y., Bustamante, R. O., Aguirre, L. F. \& Siles, M. M. 2007: Regeneration patterns of Polylepis subtusalbida growing with the exotic trees Pinus radiata and Eucalyptus globulus at Parque Nacional Tunari, Bolivia. Plant Ecology 193 (2): 253-263.

Gareca, E. E., Vandelook, F., Fernández, M., Hermy, M. \& Honnay, O. 2012: Seed germination, hydrothermal time models and the effects of global warming on a threatened high Andean tree species. Seed Science Research 22 (4): 287-298.

Gareca, E. E., Breyne, P., Vandepitte, K., Cahill, J. R., Fernandez, M. \& Honnay, O. 2013: Genetic diversity of Andean Polylepis (Rosaceae) woodlands and inferences regarding their fragmentation history. Botanical Journal of the Linnean Society 172 (4): 544-554.

Geldmann, J., Barnes, M., Coad, L., Craigie, I. D., Hockings, M. \& Burgess, N. D. 2013: Effectiveness of terrestrial protected areas in reducing habitat loss and population declines. Biological Conservation 161: $230-238$.

Giorgis, M. A., Cingolani, A. M., Teich, I., Renison, D. \& Hensen, I. 2010: Do Polylepis australis trees tolerate herbivory? Seasonal patterns of shoot growth and its consumption by livestock. Plant Ecology 207 (2): 307-319.

Goldstein, G., Meinzer, F. \& Rada, F. 1994: Environmental biology of a tropical treeline species, Polylepis sericea. In Rundel, P. W., Smith, A. P. \& Meinzer, F. C. eds. Tropical Alpine Environments: Plant Form and Function. Cambridge, United Kingdom. Cambridge University Press. p. $129-150$

Gosling, W. D., Hanselman, J. A., Knox, C., Valencia, B. G. \& Bush, M. B. 2009: Long-term drivers of change in Polylepis woodland distribution in the central Andes. Journal of Vegetation Science 20 (6) $1041-1052$

Hertel, D. \& Wesche, K. 2008: Tropical moist Polylepis stands at the treeline in East Bolivia: the effect of elevation on stand microclimate, above-and below-ground structure, and regeneration. Trees 22 (3): 303-315.

Hoch, G. \& Körner, C. 2005: Growth, demography and carbon relations of Polylepis trees at the world's highest treeline. Functional Ecology 19 (6): 941-951.
Hoffmann, D., Oetting, I., Arnillas, A. C. \& Ulloa, R. 2011: Climate change and protected areas in the tropical Andes. In Herzog, S. K., Martinez, R., Jørgensen, P. M. \& Tiessen, H. eds. Climate Change and Biodiversity in the Tropical Andes. Inter-American Institute for Global Change Research (IAI) and Scientific Committee on Problems of the Environment (SCOPE). p. 311-325.

International Union for Conservation of Nature's Red List of Threatened Species (IUCN). 2019: Polylepis. Available from: http:// www.iucnredlist.org/ [accessed 03 February 2019]

Jameson, J. S. \& Ramsay, P. M. 2007: Changes in high-altitude Polylepis forest cover and quality in the Cordillera de Vilcanota, Perú, 1956-2005. Biological Conservation 138 (1-2): 38-46.

Kessler, M. \& Driesch, P. 1993: Causas e historia de la destrucción de bosques altoandinos en Bolivia. Ecología en Bolivia 21: 1-18.

Kessler, M. \& Schmidt-Lebuhn, A. N. 2006: Taxonomical and distributional notes on Polylepis (Rosaceae). Organisms Diversity and Evolution 6 (1): 67-69.

Kessler, M. 2002: The "Polylepis problem": where do we stand. Ecotropica 8 (2): 97-110.

Kessler, M. 2006: Bosques de Polylepis. In Moraes, M., Øllgaard, B., Kvist, L. P., Borchsenius, F. \& Balslev, H. eds. Botánica Económica de los Andes Centrales. La Paz, Bolivia. Universidad Mayor de San Andrés, p. 110-120.

Kessler, M., Toivonen, J. M., Sylvester, S. P., Kluge, J. \& Hertel, D. 2014: Elevational patterns of Polylepis tree height (Rosaceae) in the high Andes of Peru: role of human impact and climatic conditions. Frontiers in Plant Science 5: 194.

Kitchenham, B., Brereton, O. P., Budgen, D., Turner, M., Bailey, J. \& Linkman, S. 2007: A Systematic Literature Review of Evidence-based Software Engineering. EBSE Technical Report. EBSE-2007-03.

Marcora, P., Hensen, I., Renison, D., Seltmann, P. \& Wesche, K. 2008: The performance of Polylepis australis trees along their entire altitudinal range: implications of climate change for their conservation. Diversity and Distributions 14 (4): 630-636.

Marengo, J. A., Ambrizzi, T., Da Rocha, R. P., Alves, L. M., Cuadra, S. V., Valverde, M. C., Torres, R. R., Santos, D. C. \& Ferraz, S. E. 2010: Future change of climate in South America in the late twentyfirst century: intercomparison of scenarios from three regional climate models. Climate Dynamics 35 (6): 1073-1097.

Mathez-Stiefel, S. L., Peralvo, M., Báez, S., Rist, S., Buytaert, W., Cuesta, F., Fadrique, B., Feeley, K. J., Groth, A. A. P., Homeier, J., Llambí, L. D., Locatelli, B., López, M. F., Malizia, A. \& Young, K. R. 2017: Research priorities for the conservation and sustainable governance of Andean forest landscapes. Mountain Research and Development 37 (3): 323-339.

Mitchell, R. E. \& Eagles, P. F. 2001: An integrative approach to tourism: Lessons from the Andes of Peru. Journal of Sustainable Tourism 9 (1): 4-28.

Morales, L. V., Fuentealba, B., Sevillano, C. S., Gómez, M. I., Segovia-Salcedo, M. C., Renison, D., Green, D., Aucca, C. \& Hensen, I. 2018b: Oportunidades para acercar la ciencia a la práctica de la restauración de bosques y arbustales de Polylepis. Ecología Austral 28: 291-300.

Morales, L. V., Sevillano-Rios, C. S., Fick, S. \& Young, T. P. 2018a: Differential seedling regeneration patterns across forest-grassland 
ecotones in two tropical treeline species (Polylepis spp.). Austral Ecology 43: 514-526.

Myers, N., Mittermeier, R. A., Mittermeier, C. G., Da Fonseca, G. A. \& Kent, J. 2000: Biodiversity hotspots for conservation priorities. Nature 403: 853-858.

Osha, J. 2000: Current stand structure of Polylepis reticulata in the Sacha Huayco forest of Ecuador and implications for regeneration. TRI News 19: 25-28.

Pacheco, K. A. 2015: Estructura de los rodales de Polylepis reticulata de Parque Nacional El Cajas. Estado actual para proyección futura en el marco del cambio climático. Tesis Ingeniera Ambiental. Cuenca, Ecuador. Facultad de Ciencias Químicas, Universidad de Cuenca. 144 p.

Parrish, J. D., Braun, D. P. \& Unnasch, R. S. 2003: Are we conserving what we say we are? Measuring ecological integrity within protected areas. AIBS Bulletin 53 (9): 851-860.

Pinos, J., Studholme, A., Carabajo, A. \& Gracia, C. 2017: Leaf Litterfall and Decomposition of Polylepis reticulata in the Treeline of the Ecuadorian Andes. Mountain Research and Development 37 (1): 87-96.

Pretell, J., Ocaña, D., Jon, R. \& Barahona, E. 1985: Apuntes sobre algunas especies forestales nativas de la sierra peruana. Proyecto FAO/ Holanda/INFUR (GCP/PER/027/NET).

Purcell, J. \& Brelsford, A. 2004: Reassessing the causes of decline of Polylepis, a tropical subalpine forest. Ecotropica 10: 155-158.

Purcell, J., Brelsford, A. \& Kessler, M. 2004: The world's highest forest: a better understanding of the properties of Andean queñua woodlands has major implications for their conservation. American Scientist 92 (5): 454-461.

Quispe-Melgar, H. R., Sevillano-Ríos, C. S., Romo, W. C. N., Ames-Martínez, F. N., Camel, V., Fjeldså, J. \& Kessler, M. 2019: The Central Andes of Peru: a key area for the conservation of Polylepis forest biodiversity. Journal of Ornithology 161: 217-228.

Rada, F., Azócar, A., Briceno, B., González, J. \& García-Núñez, C. 1996: Carbon and water balance in Polylepis sericea, a tropical treeline species. Trees 10 (4): 218-222.

Rada, F., García-Núńez, C. \& Rangel, S. 2009: Low temperature resistance in saplings and ramets of Polylepis sericea in the Venezuelan Andes. Acta Oecologica 35 (5): 610-613.

Rada, F., García-Núnez, C., Boero, C., Gallardo, M., Hilal, M., Gonzalez, J., Prado, F., Liberman-Cruz, M. \& Azócar, A. 2001: Low-temperature resistance in Polylepis tarapacana, a tree growing at the highest altitudes in the world. Plant, Cell \& Environment 24 (3): 377-381.

Rahbek, C., Borregaard, M. K., Colwell, R. K., Dalsgaard, B., Holt, B. G., Morueta-Holme, N., Nogues-Bravo, D., Whittaker R. J. \& Fjeldså, J. 2019: Humboldt's enigma: What causes global patterns of mountain biodiversity? Science 365: 1108-1113.

Renison, D., Cingolani, A. M. \& Suarez, R. 2002: Efectos del fuego sobre un bosquecillo de Polylepis australis (Rosaceae) en las montañas de Córdoba, Argentina. Revista Chilena de Historia Natural 75 (4): 719-727.

Renison, D., Cingolani, A., Suarez, R., Menoyo, E., Coutsiers, C., Sobral, A. \& Hensen, I. 2005: The restoration of degraded mountain woodlands: effects of seed provenance and microsite characteristics on Polylepis australis seedling survival and growth in central Argentina. Restoration Ecology 13 (1): 129-137.
Renison, D., Hensen, I. \& Cingolani, A. M. 2004: Anthropogenic soil degradation affects seed viability in Polylepis australis mountain forests of central Argentina. Forest Ecology and Management 196 (2-3): $327-333$.

Renison, D., Hensen, I. \& Suarez, R. 2011: Landscape structural complexity of high-mountain Polylepis australis forests: a new aspect of restoration goals. Restoration Ecology 19 (3): 390-398.

Renison, D., Hensen, I., Suarez, R., Cingolani, A. M., Marcora, P. \& Giorgis, M. A. 2010: Soil conservation in Polylepis mountain forests of Central Argentina: is livestock reducing our natural capital? Austral Ecology 35 (4): 435-443.

Renison, D., Morales, L., Cuyckens, G. É., Sevillano, C. S. \& Amaya, D. M. C. 2018: Ecología y conservación de los bosques y arbustales de Polylepis: ¿qué sabemos y qué ignoramos? Ecología Austral 28: 163-174.

Romoleroux, K. 1996: 79 Rosaceae. In Harling, G. \& Andersson, L. eds. Flora of Ecuador. University of Gothenburg/Riksmuseum/ Pontificia Universidad Católica del Ecuador, Göteborg/Stockholm/ Quito. 56: 1-152.

Saravia, G. \& Vintimilla, D. 2016: Actividad vegetativa, tasas de crecimiento y estimación de la edad de los individuos en los rodales de Polylepis reticulata del Parque Nacional Cajas. Tesis Ingeniera Ambiental. Cuenca, Ecuador. Facultad de Ciencias Químicas, Universidad de Cuenca. 115 p.

Saura, S., Bertzky, B., Bastin, L., Battistella, L., Mandrici, A. \& Dubois, G. 2018: Protected area connectivity: Shortfalls in global targets and country-level priorities. Biological Conservation 219: 53-67.

Schmidt-Lebuhn, A. N., Kessler, M. \& Kumar, M. 2006: Promiscuity in the Andes: species relationships in Polylepis (Rosaceae, Sanguisorbeae) based on AFLP and morphology. Systematic Botany 31 (3): $547-559$.

Segovia-Salcedo, M. C., Domic, A., Boza, T. \& Kessler, M. 2018: Situación taxonómica de las especies del género Polylepis. Implicancias para los estudios ecológicos, la conservación y la restauración de sus bosques. Ecología Austral 28: 188-201.

Seltmann, P., Leyer, I., Renison, D. \& Hensen, I. 2007: Variation of seed mass and its effects on germination in Polylepis australis: implications for seed collection. New Forests 33 (2): 171-181.

Sevillano, C., Rodewald, A. D. \& Morales, L. V. 2018: Ecología y conservación de las aves asociadas con Polylepis: ¿qué sabemos de esta comunidad cada vez más vulnerable? Ecología Austral 28: 216-228.

Smith, A. P. 1978: Establishment of seedlings of Polylepis sericea in the páramo (alpine) zone of the Venezuelan Andes. Bartonia 45: 11-14.

Simoes-Macayo, N. \& Renison, D. 2015: ¿Cuántos ańos monitorear el éxito de plantaciones con fines de restauración?: Análisis en relación al micrositio y procedencia de las semillas. Bosque 36 (2): 315-322.

Simpson, B. B. 1979: A Revision of the Genus Polylepis (Rosaceae: Sanguisorbeae). Smithsonian Contributions to Botany. Washington DC: Smithsonian Institution Press. p. 1-62.

Simpson, B. B. 1986: Speciation and specialization of Polylepis in the Andes. In Viulleumier, F. \& Monasterio, M. eds. High Altitude Tropical Biogeography. New York, USA. Oxford University Press. p. 304-316. 
Swamy, L., Drazen, E., Johnson, W. R. \& Bukoski, J. J. 2018: The future of tropical forests under the United Nations Sustainable Development Goals. Journal of Sustainable Forestry 37 (2): 221-256.

Teich, I., Cingolani, A. M., Renison, D., Hensen, I. \& Giorgis, M. A. 2005: Do domestic herbivores retard Polylepis australis Bitt. woodland recovery in the mountains of Córdoba, Argentina? Forest Ecology and Management 219 (2-3): 229-241.

Toivonen, J. M., Gonzales-Inca, C. A., Bader, M. Y., Ruokolainen, K \& Kessler, M. 2018: Elevational shifts in the topographic position of Polylepis forest stands in the Andes of southern Peru. Forests 9 (1): 7.

Toivonen, J. M., Kessler, M., Ruokolainen, K. \& Hertel, D. 2011: Accessibility predicts structural variation of Andean Polylepis forests. Biodiversity and Conservation 20 (8): 1789-1802.

Torres, R. C., Renison, D., Hensen, I., Suarez, R. \& Enrico, L. 2008: Polylepis australis' regeneration niche in relation to seed dispersal, site characteristics and livestock density. Forest Ecology and Management 254 (2): 255-260.

Urrutia, R. \& Vuille, M. 2009: Climate change projections for the tropical Andes using a regional climate model: Temperature and precipitation simulations for the end of the 21st century. Journal of Geophysical Research: Atmospheres 114: D2

Valencia, B. G., Bush, M. B., Coe, A. L., Orren, E. \& Gosling, W. D. 2018: Polylepis woodland dynamics during the last 20,000 years. Journal of Biogeography 45 (5): 1019-1030.
Villarroel, E. K., Mollinedo, P. L. P., Domic, A. I., Capriles, J. M \& Espinoza, C. 2014: Local management of Andean wetlands in Sajama National Park, Bolivia: persistence of the collective system in increasingly family-oriented arrangements. Mountain Research and Development 34 (4): 356-368.

Winters, P., Crissman, C. C. \& Espinosa, P. 2004: Inducing the adoption of conservation technologies: lessons from the Ecuadorian Andes. Environment and Development Economics 9 (5): 695-719.

Wittemyer, G., Elsen, P., Bean, W. T., Burton, A. C. O. \& Brashares, J. S. 2008: Accelerated human population growth at protected area edges. Science 321: 123-126.

Zimmermann, H., Renison, D., Leyer, I. \& Hensen, I. 2009: Do we need livestock grazing to promote Polylepis australis tree recruitment in the Central Argentinean Mountains? Ecological Research 24 (5): 1075-1081.

Zutta, B. R., Rundel, P. W., Saatchi, S., Casana, J. D., Gauthier, P., Soto, A., Velazco, Y. \& Buermann, W. 2012: Prediciendo la distribución de Polylepis: bosques Andinos vulnerables y cada vez más importantes. Revista Peruana de Biología 19 (2): 205-212. 